\title{
THE IMPLEMENTATION OF MARRIAGE GUIDANCE FOR PROSPECTIVE BRIDALS BY THE RELIGION MINISTRY OF MANADO
}

\section{Salma}

Faculty of Sharia, Institut Agama Islam Negeri Manado, Sulawesi Utara, Indonesia, Jl. Dr. S.H. Sarundaiang Kawasan Ring Road I Kota Manado, 95128 E-mail: salma.mursyid@iain-manado.ac.id

\author{
Ahmad Rajafi \\ Faculty of Sharia, Institut Agama Islam Negeri Manado, Sulawesi Utara, \\ Indonesia, Jl. Dr. S.H. Sarundajang Kawasan Ring Road I Kota Manado, 95128 \\ E-mail: ahmad.rajafi@gmail.com
}

\begin{abstract}
Divorce in Manado includes the highest in North Sulawesi, while the office of Religious Affairs has long run the course for prospective brides. After that, it brought forth a new regulation on marriage guidance brides was born in 2009 with a detailed curriculum and modules in 2016. This marriage guidance is the urgency of this research to examine the implementation of marriage guidance in Manado's city. This research's field is qualitative with data collection through observation, interviews, documentation, and the SWOT analysis approach. The results were found that many obstacles in the level of implementation, from disproportionate budgeting, not using a certified facilitator, the implementation that was not in accordance with the technical guidelines namely for sixteen hours of learning divided into two days; with a division of time of eight hours on the first day and eight hours on the second day.
\end{abstract}

Keywords: Implementation; Marriage Guidance; Prospective Bride

How to Cite: Salma, \& Rajafi, A. (2020). The Implementation of Marriage Guidance for Prospective Bridals by the Religion Ministry of Manado. Jurnal Ilmiah Al-Syir'ah, 18(2), 112-126.

Permalink/DOI: http://dx.doi.org/10.30984/jis.v18i2.1192

Copyright (C) 2020, Jurnal Ilmiah Al-Syir'ah 


\section{INTRODUCTION}

Marriage and divorce have such strong relationships; a healthy marriage will result in household permanence, while an unhealthy marriage will result in systematic household damage, implying divorce and psychological disruption in the family, especially for children (broken home).

As for Manado as a modern city, it is often referred to as an international city because it is a favorite national and international tourist destination. Its main icon is marine tourism on the island of Bunaken. It is an area with the Muslim community as a minority. Theoretically, for groups with unique similarities, even more so if a minority will have a distinctive impact in the sense that it will be easy to help and protect each other (Hogg \& Abrams, 1988). This statement means that as a minority Muslim community in Manado City, they can look after each other, including maintaining the household's integrity because the natural system requires this. Still, in reality, Muslims in Manado City are among the most responsible for divorce quantity.

Data in the High Court of Religion of North Sulawesi Province shows the high divorce rate at the end of 2018, reaching 1,706 cases. Of these cases, the Kotamobagu City area is in the highest number and follow by Manado City (Adm, 2018; Assa, 2018). As for those who filed for divorce at the Court aged 30-35 years (Sekeon, 2019), the age is still productive in building a household.

This data is counterproductive if it is related to the government's enthusiasm. To build a happy family through various pre-marriage mentoring programs, such as; Candidate Bride Course at the Office of Religious Affairs, based on the Decree of the Minister of Religion No. 477 of 2004 concerning the provision of insight into marriage and household to prospective brides through the bride and groom course, as well as the Circular of the Director-General of Islamic Community Guidance No. DJ.II / PW.01 / 1997/2009; and Marriage Guidance carried out by the Islamic Community Guidance of the District/City Religious Office based on the Decree of the Director-General of Islamic Community Guidance No. 379 of 2018 concerning Instructions for Implementing Pre-Marriage Guidance for Prospective Brides.

Not only providing normative instructions, but the state also issued a Marriage Guidance Module for Bride-to-be, with the hope that new families who have received marriage guidance will be able to become strong families and not easily collapse (Rofiah \& Kustini, 2016). However, even though the state has made every effort, the divorce rate is still high. This state could be due to ineffective implementation, because without effective implementation, policymakers' decision will not be successful (Edwards III, 1984). 
In more detail, Van Meter and Horn explained that policy implementation's main objective is to achieve goals (Wibawa, 1994). The gap between theory and practice above requires an in-depth study of how to model the implementation of the bride and groom course or marriage guidance organized by the Ministry of Religion in Manado City.

These problems can definitively explain that the word implementation means implementation or application (Kemendikbud, 2019). In Islamic studies, the term commonly used to denote the meaning of performance is at-tathbiq (Munawwir, 1997), as said al-ijtihad.fi tathbiq an-nash, tathbiq asy-syari'ah, and so on. The term implementation means a mode of implementing ideas, concepts, policies, or innovations in the form of practical actions that impact, either in the form of changes in knowledge, skills, and values and attitudes (Hamalik, 2007).

The marriage guidance is a new program from the Ministry of Religion of the Republic of Indonesia in the framework of the prospective bride and groom's education. The main essence of marriage guidance directed by the Minister of Religion is as a learning space about the secrets of a marriage. For this reason, a module makes as to the primary means or curriculum in carrying out the marriage guidance (Kurniawan, 2018).

Based on the two definitions of these terms. Previous research that explicitly examines marriage guidance in Manado and outside Manado has not been found, except for old research that discusses the Candidate Bride Course, such as a journal article from Zulkfli Wahab (2017), which discusses the process of implementing the course. Bride and groom in the Office of Religious Affairs in Tamalanrea and Biringkanaya Districts. The results of this study indicate that organizing a bridegroom course at the Office of Religious Affairs in the District of Tamalanrea and Biringkanaya, Makassar, does not meet the system's target time. It seems ceremonial and ignores the essence of the bride-to-be course.

Muhammad Lutfi Hakim wrote another study on the Pre-Marriage Course, which compared the Marriage Advisory and Preservation Agency's work for the Religious Affairs Office of East Pontianak District and the West Kalimantan Christian Church, the Pontianak Congregation. The results of this study indicate that the two of them have no principal differences, except only in technical matters, because both have the same goal of providing education for the prospective bride and groom in forming a sakinah, mawaddah, and rahmah family (Hakim, 2016).

The two studies show a distinction between this research, namely in research material where the two studies above lead to the old material because it examines the bride and groom course and the pre-marriage course. In contrast, this research leads to the new material, namely on marriage guidance. Apart from that, the research's locus is also different, and the uniqueness of this research is the locus, where Manado is an urban area dominated by Protestant Christians. Islam is a minority religion, so the assumption that is built is that Islam is a minority religion then the household problem. There shouldn't be a lot either, but the fact is that with

The Implementation of Marriage Guidance for Prospective Bridals by the Religion Ministry of Manado 
the mode of course of the prospective bride and groom, the household problem is still so significant, so in this study, it is necessary to examine the method of marriage guidance in its implementation aspect.

Based on the information above, the object of this research article is a scientific review of the implementation of marriage guidance for prospective brides by the Ministry of Religion of the City of Manado through the SWAT approach so that a more effective solution is born in realizing the formation of a happy family in society.

\section{RESEARCH METHODS}

This research is field research with a qualitative approach to describe the implementation of marriage guidance for prospective brides in the Ministry of Religion, Manado City. Data obtained through; field observations at the Office of the Ministry of Religious Affairs in Manado City from December 2019 to January 2020; interviews with resource persons in January, namely the Head of the Islamic Community Guidance Section of the Ministry of Religion, Manado City and two certified facilitators in North Sulawesi Province; as well as documentation. Based on the field data obtained, the analysis knife used to analyze the implementation is a SWOT analysis (Strength, Weakness, Opportunity, and Threat). SWOT analysis is a strategy development mode in terms of the situation around the company in influencing company performance (Rangkuti, 2015).

\section{RESULTS AND DISCUSSION}

\section{Regulation in Marriage Guidance}

Based on the contents of the points in the Marriage Guidance Module for Bride and Groom Candidates (Rofiah \& Kustini, 2016), it is found that there is a reason for composing the book because the main task of marriage guidance is; 1 ) Participants in the direction are 10 to 15 pairs of prospective brides so that there are at least 10 to 15 prospective grooms and 10 to 15 future brides; 2) The guidance process is fully escorted from start to finish by the Bridegroom Guidance Team from the Office of Religious Affairs and or the local Ministry of Religion Office; 3 ) The overall duration of guidance is 16 hours, divided into two days, each of eight hours; 4) The first day of the guidance process is fully managed by the Guidance Team from the Office of Religious Affairs and/or the local Ministry of Religion Office, both facilitators and resource persons; 5) The second day of the guidance process is managed by the Guidance Team from the Office of Religious Affairs and or the local Ministry of Religion Office as a facilitator, while the resource persons come from other ministries or institutions.

Through the Module's implementation model's provisions, two main priorities are born, namely; (1) strengthening the prospective bride and groom's perspective on marriage and family, and (2) training in specific skills to manage marriages and families. Learning in marriage guidance is people who are 
considered capable and mature. The primary education model starts from being actively involved in the learning process, learning materials that are directly related to their daily lives. Useful material can be applied in their lives, given the opportunity to take advantage of their knowledge, abilities, and skills in the learning process. The learning process takes into account experiences and thinking power (Rofiah \& Kustini, 2016).

For all the content of learning in marriage guidance to be adopted and become a guide for the prospective bride and groom, several stages were carried out, namely: (1) Expressing, by inviting participants to share their experiences, then asking for their responses or impressions on the backgrounds; (2) Analyze, by encouraging participants to find patterns by examining the causes and linkages of the problems that exist in the experience, for example, related to the order, rules, values, systems, or other things that are the root of the problem; (3) To conclude encouraging them to conclude by formulating the meaning of the experience with a new, complete perspective and understanding in the form of general principles or conclusions; (4) Experiencing, by inviting participants to plan new and better actions based on the results of this new understanding or understanding, so that it is possible to create new, better realities (Rofiah \& Kustini, 2016).

Through all the provisions above, in essence, it is returned to the expertise of the facilitators. Those who can encourage marriage guidance to be more effective and efficient for all future brides. For this reason, the Module states the obligations of a facilitator, namely: (1) Ensure that the subject matter of each material can process completely; (2) Controlling the time so that each material has an appropriate time allocation according to the schedule; (3) Escorting the resource person to deliver material following the subject matter contained in the Module; (4) Encourage each participant to be active in the process and prevent the forum's domination by individual participants, resource persons, and even the facilitators themselves (Rofiah \& Kustini, 2016).

The materials that must deliver in marriage guidance based on this Module are (Rofiah \& Kustini, 2016):

Table 1. Per-Session Material

\begin{tabular}{|c|c|c|}
\hline & Module 1 & Module 2 \\
\hline $\begin{array}{c}\text { Session } \\
1\end{array}$ & Introduction and Study Contract & Maintain family reproductive health \\
\hline $\begin{array}{l}\text { Session } \\
2\end{array}$ & $\begin{array}{l}\text { Preparing for a Strong Marriage Towards a } \\
\text { Sakinah Family }\end{array}$ & Preparing a Quality Generation \\
\hline $\begin{array}{l}\text { Session } \\
3\end{array}$ & Managing Marriage and Family Dynamics & $\begin{array}{l}\text { Managing Conflict and Building Family } \\
\text { Resilience }\end{array}$ \\
\hline $\begin{array}{c}\text { Session } \\
4 \\
\end{array}$ & Meeting Family Needs & Reflection and Evaluation \\
\hline
\end{tabular}

Source: Field Data at the Ministry of Religion, Manado, 2019 
Jurnal Ilmiah Al-Syir'ah Vol. 18, No. 2 (2020): 112-126

Website: http://journal.iain-manado.ac.id/index.php/JIS

ISSN 2528-0368 (online) ISSN 1693-4202 (print)

Table 2. Schedule of Marriage Guidance Activities

\begin{tabular}{|c|c|c|c|}
\hline Day & Time & Materials & Responsible \\
\hline \multirow{7}{*}{$\mathbf{I}$} & 08.00-08.30 & Pre-Test and Opening & $\begin{array}{l}\text { Advisor Team (Facilitator } \\
\text { and Committee) }\end{array}$ \\
\hline & $08.30-10.00$ & Introduction and Study Contract & Advisor Team (Facilitator) \\
\hline & $10.00-12.00$ & $\begin{array}{l}\text { Preparing for a Strong Marriage } \\
\text { towards a Sakinah Family }\end{array}$ & $\begin{array}{l}\text { Advisor Team (Facilitators/ } \\
\text { Resource Persons) from the } \\
\text { Indonesian Ministry of } \\
\text { Religion }\end{array}$ \\
\hline & $12.00-13.00$ & Rest, lunch, and Dhuhr prayer & Advisor Team (Committee) \\
\hline & $13.00-15.00$ & $\begin{array}{l}\text { Managing Marriage and Family } \\
\text { Dynamics }\end{array}$ & $\begin{array}{l}\text { Advisor Team (Facilitators / } \\
\text { Resource Persons) from the } \\
\text { Indonesian Ministry of } \\
\text { Religion }\end{array}$ \\
\hline & $15.00-17.00$ & Meeting Family Needs & $\begin{array}{l}\text { Advisor Team (Facilitators / } \\
\text { Resource Persons) from the } \\
\text { Indonesian Ministry of } \\
\text { Religion }\end{array}$ \\
\hline & $08.00-10.00$ & $\begin{array}{l}\text { Maintaining Family Reproductive } \\
\text { Health }\end{array}$ & $\begin{array}{l}\text { Advisor Team (Facilitator) } \\
\text { and Resource Persons from } \\
\text { the Ministry / Service }\end{array}$ \\
\hline \multirow{5}{*}{ II } & $10.00-12.00$ & Preparing a Quality Generation & Health \\
\hline & $12.00-13.00$ & Rest, lunch, and Dhuhr prayer & $\begin{array}{l}\text { Advisor Team (Facilitator) } \\
\text { and Resource Persons from } \\
\text { the Ministry / Service }\end{array}$ \\
\hline & $13.00-15.00$ & $\begin{array}{l}\text { Managing Conflict and Building } \\
\text { Family Resilience }\end{array}$ & Education \\
\hline & $15.00-16.30$ & Reflection and Evaluation & Advisor Team (Committee) \\
\hline & $16.30-17.00$ & Post-Test and Closing & $\begin{array}{l}\text { Advisor Team (Facilitator) } \\
\text { and Resource Persons from } \\
\text { the Ministry / Service }\end{array}$ \\
\hline
\end{tabular}

Source: Field Data at the Ministry of Religion, Manado, 2019

The data in this study obtained through observation and interviews and documentation. The observation context finds that marriage guidance in Manado City still has not applied one hundred percent technical guidelines and module books in carrying out marriage guidance as published by the Indonesian Ministry of Religion. Practices in the field have two models, namely traditional marriage advice, namely in marriage in the form of lectures by the mosque's local Imam or invited religious leaders. The government carries out the second one, in this case, the Municipal Ministry of Religion. Manado and or the Office of Religious Affairs.

Regarding marriage guidance carried out by the government, there are two models applied, namely applying the old model in the form of bride and groom courses by the Office of Religious Affairs which conduct before the marriage contract takes place. The second is marriage guidance carried out by the Ministry of Religion of Manado City by inviting all The Office of Religious Affairs to present existing prospective brides to participate in this activity. 
Based on the results of interviews with the Head of Manado Islamic Community Guidance Section (Interview with Bacharuddin, Head of the Islamic Community Guidance Section of the Manado City Ministry of Religion Office, January 22, 2020). It finds that the Manado City Religious Office's implementation of marriage guidance was one year once since the enactment of the rules on marriage guidance. This guidance is due to the lack of budget, so that they can only plan this way. For example, activities published in electronic media are in 2018, namely Adolescent Marriage Guidance for Marriage (Adm, 2018), and the Ministry of Religion Provides Pre-Marriage Guidance to 25 Catin Couples (Jefry, 2018). In 2019, Marriage Guidance for Marriage Aged Teens was attended by 40 teenagers, and Pre-Marriage Guidance for Prospective Bride follow by 25 couples (Ranti, 2019).

All series of marriage guidance activities have not been able to follow the Module in the activity time, which requires eight hours of lessons every day for two days. The total hours of marriage guidance learning must complete as many as sixteen hours, only finished in a few hours in one day. The meaning even one day does not reach eight hours of lessons (Interview with Bacharuddin, Head of Section of Islamic Community Guidance, Office of the Ministry of Religion, Manado City, January 22, 2020). Thus, because not all of the bride and groom-to-be follow marriage guidance based on modules, moreover, the model implemented also varies between the Ministry of Religion of Manado City and the Office of Religious Affairs, all of these marriage guidance activities cannot be considered as effective activities and are only ceremonial in nature we can be sure that it will be able to provide optimal reinforcement to all prospective brides in maintaining household harmony so that divorce does not occur in the future.

More about this source text When extracted about the facilitators' information, it was found that there were only two certified facilitators who are domiciled in Manado City, namely Muh. Rusdi Musanif, who serves as Head of the Section for Development of Sakinah Family Development at the Regional Office of the Ministry of Religion of North Sulawesi Province and Kisman Munte Penghulu, the Office of Religious Affairs at the Office of the Ministry of Religion in Manado City. However, when asked, two of them were facilitators in the Ministry of Religious Affairs' marriage guidance activities in Manado. They never made facilitators due to a lack of information about both of them who had become certified facilitators.

The information about marriage guidance, an interview was conducted with one of the facilitators, Muh. Rusdi Musanif (January 22, 2020). There is some information that can obtain the effectiveness of marriage counseling from those concerned. The informant, an official in sciences at the Regional Office of the Ministry of Religion of North Sulawesi Province, explained that certified facilitators in North Sulawesi. Including the City of Manado, are still very minimal, considering that education or training on marriage guidance facilitators is limited in terms of implementation time and the limited quota of participants from the center. 
Musanif (January 22, 2020) explained that the law number of certified facilitators, they could not attend many activities from the Regency/City. Even in one year, there can be twenty marriage guidance activities, with various participants, namely the prospective bride and the groom. This bridge is also why not reaching the learning time of up to sixteen hours or two days of activity totaling eight hours per day.

Even so, the materials he delivered were still sourced from the Module but with improvisations from him. Improvisation is essential according to him because of the limited time for various participants, which requires the delivery of different materials between the prospective brides who are adults and the age of marriage. In contrast, according to him, the prospective bride and the marriage participants must be separated so that the material will deliver effectively. Apart from that, the extended distance from the prospective bride and groom's residence to the activity location is also an obstacle, especially for those who live in archipelagic areas. Follow marriage guidance (Interview with Musanif, Certified Facilitator of Marriage Guidance January 22, 2020).

The obstacle in implementing marriage guidance for facilitators, even though the concept of marriage guidance is almost the same as the lecture program from the idea of college contracts to evaluation so that the optimization of activities will not achieve. It is also possible that marriage guidance like this will not necessarily minimize problems in the family. Therefore, Musanif said that the existing regulations were already perfect. Still, they were generalistic. With its anthropologic, sociological, and even economic differences, Manado could not optimally implement technical guidelines and marriage guidance modules (Interview with Musanif, Certified Marriage Guidance Facilitator, January 22, 2020).

\section{SWOT Analysis of Marriage Guidance Activities in Manado}

Evaluation carries out using a SWOT analysis (strengths, weaknesses, opportunities, and threats) (Rangkuti, 2015). This analysis is useful for knowing the state of marital guidance activities implemented by the Ministry of Religion of Manado City based on their strengths, weaknesses, opportunities, and threats, but with a qualitative narrative.

\section{Strength}

Marriage guidance base on the Module for Bride and Groom Candidates published by the Religion Ministry of Republic of Indonesia (2016). The book Foundations of Sakinah Families: Readings of Candidates for the Bride, published by the Indonesian Ministry of Religion (2017), as well as the Decree of the DirectorGeneral of Islamic Community Guidance Number 373 the year 2017 concerning the Technical Guidance for Marriage Guidance for Bride and Groom Candidates, is the central norm for the implementation of marriage guidance in all regions in Indonesia including the city of Manado. 
Normatively, the strength of marriage guidance can see clearly. First, in the context of financing, prospective brides do not need to think about the budget spent in obtaining good marriage knowledge towards sakinah, mawaddah and rahmah, because the funding for marriage guidance activities is borne by DIPA of the Directorate General of Islamic Community Guidance.

Second, in the context of implementation, the state welcomes three choices for implementing marriage guidance, namely the local Ministry of Religion, the Office of Religious Affairs, or other institutions that have met the Ministry of Religion requirements. This implementation means that whoever is getting married or becoming a prospective bride will choose marriage guidance depending on which one will make it easier for them, considering low costs in the context of travel costs.

Third, in the temporal context, marriage guidance presents a very scientific and practical training because a very detailed learning manual guides it. The material presented is juxtaposed with various correlated games so that the marriage guidance participants do not feel bored in following the marriage guidance material from the facilitators.

Fourth, in the context of facilitators and resource persons, the state requires facilitators to have a certificate after passing the marriage guidance facilitator education. This statement means that the marriage guidance activities are not playing games because the facilitator is a professional person who is very knowledgeable about all plans for marriage guidance activities with various family problems that must be answered when asked by the participants. Other sources are from the Religion Ministry and other parties, such as knowledge of health from the Health Ministry. The explanation of good communication and legal implications if it applies negatively to wives and children from the Ministry of Women and Child Protection, knowledge of solving good household problems based on religious and state knowledge from the Religious Courts, etc.

Fifth, in the context of activity time, the state formulates the duration of marriage guidance activities for sixteen hours, which divide into two sessions. The first session is held for one day throughout eight hours of lessons, and the second session is held on the second day for eight hours of classes. The time that is very detailed between each material shows the professionalism of time management from the marriage guidance organizer. No time waste and the marriage guidance participants will get excellent benefits from the time formula.

\section{Weaknesses}

We can see the strengths of the legal norms established by the state. In that case, the weaknesses can be seen from the implementation of marriage guidance by the Ministry of Religion of Manado City. First, inactivity budgeting, the Islamic Community Guidance of the Ministry of Religion of Manado complained about the lack of budget for marriage guidance activities in Manado City. The 
implementation of activities can only take place once a year. At the same time, the number of prospective brides is always available every month.

Second, in the context of the number of marriage guidance participants, the government, based on the Module, explains that the number of participants ranges from ten to fifteen pairs of prospective brides. Still, because of the implementation of marriage guidance by the Office of the Ministry of Religion of the City of Manado, in this case, the Islamic Community Guidance is only done once a day. one year. As a result, the participants can exceed 20 pairs of prospective brides.

Third, in the context of marriage guidance facilitators who must be certified, the Ministry of Religion of Manado City has not used certified facilitators in recent years due to the limited number of accredited facilitators in Manado City. Even the existing facilitators are due to the education facilitated by the Regional Office of the Ministry of Religion of North Sulawesi Province to be more empowered outside Manado City as facilitators. They can even carry out up to twenty activities.

Fourth, in education time, the government has stipulated an obligation of sixteen hours of lessons divided into two days. Each day is eight hours of study in the implementation of marriage guidance. However, in reality, none of the performances of marriage guidance by the Ministry of Religion of Manado follow these regulations. This regulation is due to the lack of a budget that can only carry out one day. The second is because the distance traveled by participants to the activity location is quite far, especially those who live in island areas, and the third is because the prospective brides who become participants also have routine jobs every day and may not have to leave their work for two full days so that the effectiveness of the activities expected in two days is a problem for the participants. As a result, the participants would not be possible to participate in marriage guidance activities for two consecutive days, let alone up to eight hours per day.

Fifth, in the context of resource persons outside the Ministry of Religion, the Islamic Community Guidance at the Office of the Ministry of Religion of the City of Manado is still unable to present external sources such as the Ministry of Health to explain the importance of having a healthy family. The Ministry of Women and Child Protection define the prohibition of domestic violence. To spouses (husband or wife) and children and the Religious Courts to explain the importance of maintaining a family and the right solution in case of conflicts within the family based on Islamic teachings.

\section{Chance}

Opportunity is an external factor in marriage guidance activities by the Islamic Community Guidance of the Ministry of Religion of the City of Manado, which contributes to marriage counseling success. First, the emergence of local government support beyond the support of the Ministry of Religion in Manado City, especially in terms of providing facilities and budgeting for the success of marriage

The Implementation of Marriage Guidance for Prospective Bridals by the Religion Ministry of Manado 
guidance activities in the community if a satisfactory evaluation is born from implementing the marriage guidance.

Second, in the context of the existence of choices for the community in following marriage guidance, this shows the openness of opportunities for other institutions to participate in carrying out marriage guidance activities. Islamic campuses as Islamic Colleges, Islamic Institutes, or State and Private Islamic Universities run the Islamic Family Law Study Program (Ahwal Syakhshiyyah). Can form an administrative center to carry out marriage guidance activities seriously so that they have a fair assessment of the Ministry of Religion and obtain an implementation or operational permit.

Third, in the context of the results of the transfer of knowledge from the facilitators to the marriage guidance participants, if it is carried out properly and in accordance with applicable regulations, it will provide positive opportunities for the prospective brides and other participants to open their thinking insights such as the age of marriage regarding material-Other material outside of family fiqh material is also very important to be known and understood together by their respective prospective partners, so that is why marriage guidance activities are followed by the two pairs of candidates for the bride and groom, not only by one of them, because if there is a positive understanding of the knowledge in outside of family fiqh is only known and understood by one person from the prospective bride, it will only give birth to an imbalance of thought within the family or in the context of fiqh it is called no sekufu, as implicitly expressed in the saheeh hadith:

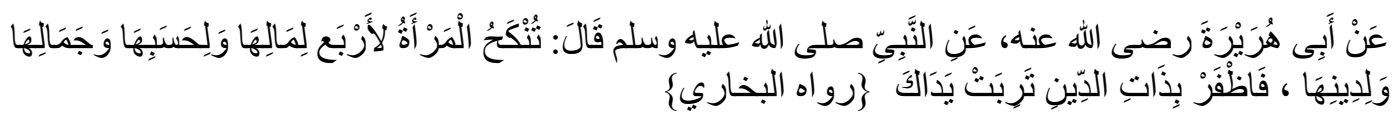

Meaning: "From Abi Hurairah Ra that the Messenger of Allah had said; the woman is married for four reasons; because of his religion, lineage, wealth and beauty, then pay attention to his faith, then you will be saved."

Fourth, in the context of optimizing activities. The vision of sakinah, mawaddah, and rahmah can be achieved for the prospective brides who are participants of marriage guidance. The practical and optimal implementation of the activity implementer is the Islamic Community Guidance at the Office of the Ministry of Religion of Manado City, based on technical guidelines on marriage guidance. The marriage guidance module and all other materials outside of marriage will provide a substantial opportunity to birth a vision of sakinah, mawaddah and rahmah in family life for future brides.

Fifth, in the context of the opportunity to reduce the will and number of divorces for married couples, marital guidance activities have a great opportunity to make a paradigm shift and build memories that will be easily remembered in the future. When there is a conflict between husband and wife and also other conflicts with other family members. The situation can happen when the prospective bride 


\section{Jurnal Ilmiah Al-Syir'ah Vol. 18, No. 2 (2020): 112-126 \\ Website: http://journal.iain-manado.ac.id/index.php/JIS ISSN 2528-0368 (online) ISSN 1693-4202 (print)}

and groom follow all the material in the facilitator's marriage guidance activities and review the materials learned when returning home and are active in all forms of discussion, especially preparing various questions about household problems. Both in the context of fiqh, health, husband-wife relations, and with children and other family members, as well as legal knowledge about marriage settlement so that divorce does not have a negative effect on one of the spouses/or children.

\section{Threats}

The analysis in finding the threat element becomes urgent because it can see whether marriage guidance activities can take place continuously in the future. The referred in management science, elements of threat can be seen from the number of competitors, the availability of resources, the duration of consumer interest, etc. For this reason, formulating a list of threats from marriage guidance activities can provide both short and long-term benefits, and the draft can continue to change based on changes in time.

First, suppose the marriage guidance activity relies only on ceremonial interests and/or only to spend the budget already available in the Work Plan and Budget of the State Ministries/Institutions (hereinafter referred to as RKAKL). In that case, this will be a threat to the sustainability of marriage guidance activities when the budget is not available or is not planned for these activities due to the leadership's considerations in the work meeting, not occur in the coming years. Therefore, it takes a sense of responsibility and a sense of belonging from the manager of marriage guidance activities. They can prepare a budget and work plan that is structured, professional, and does not rely on momentary interests, let alone ceremonial, because the benefits of marriage guidance are enormous for the prospective bride and groom as a participant.

Second, suppose the number of certified facilitators for marriage guidance does not increase in the future. In that case, it can be assumed that the material presented is not following the wishes in the technical guidelines for marriage guidance by the central government. Therefore, it is an essential program for the Islamic Community Guidance of the Ministry of Religion of the City of Manado to increase human resources by including leaders in educational activities or training on certified facilitators organized by the Indonesian Ministry of Religion.

Third, suppose the time for marriage guidance education that has been determined by the government for sixteen hours is never carried out. In that case, this may not achieve the will of a marriage's vision, namely sakinah, mawaddah, and rahmah, and allows the complete delivery of material from the facilitators to the participants not to be realized. The prospective bride and groom as participants so that a happy marriage paradigm will not be carried out perfectly for them. The implication threatens the prospective bride and groom's continuity to marry because it can be assumed that this will increase the number of divorce cases that continue to increase every year in Manado City. The knowledge that is thoroughly conveyed 
and embedded in everyone's memory will be more lasting and become a solution to every family problem that strikes.

\section{CONCLUSION}

The rules regarding marriage guidance are excellent and have strengths and advantages if implemented correctly. Still, in reality, there are many obstacles in implementation, both due to office administration factors and the lack of synergy between organizers and participants.

This marriage guidance activity's strengths are; Participants do not need to spend money because the state has facilitated them. The participants can choose a big win manager as required. The material comes from systematic modules and books so that it is easy to learn. The material deliverer or the facilitator is classified as professional because it must be certified. With a well-termed time, all the materials will change the participants' mindset to become happy families.

The weakness is the implementation side. A minimal budget exceeds the quota because it is only implemented once a year has not empowered certified facilitators due to the limited number of facilitators. The sixteen hours of education time has not been reached and is unable to bring in external resource persons due to financial factors.

The chance that can be obtained if it is serious about creating local government support in budgetary facilities and others. Information disclosure to collaborate with other parties as organizers, due to the lack of certified facilitators there is an opportunity for an increase in the number of human resources to attend facilitator education, optimization of activities will strengthen the vision of sakinah, mawaddah, and rahmah. And able to reduce the divorce rate in the city of Manado.

The threats are; The reasons for the budget that have implications for ceremonial-based implementation will threaten the continuity of significant win activities in the future, the lack of facilitators who continue to be ignored, and the inadequacy of performance. Based on technical guidelines will threaten the imperfect delivery of material to participants. It threatens the family's sustainability after education because it will be an additional number of divorces in Manado City.

\section{ACKNOWLEDGMENTS}

The author would like to thank the Rector of IAIN Manado for his support and direction so that this article can be completed and published. Thanks to the Head of the Office of the Religion Ministry of Manado, the author, all their staff, and all parties involved in completing this article. 


\section{REFERENCES}

Adm. (2018). Bimbingan Perkawinan Remaja Usia Nikah Kemenag Manado. Kanwil Kementerian Agama Provinsi Sulawesi Utara. https://sulut.kemenag.go.id/detail_berita.php?id=502985/BimbinganPerkawinan-Remaja-Usia-Nikah-Kemenag-Manado

Assa, H. F. (2018). Mengakhiri Tahun 2018 Di SULUT, Perkara Cerai Meningkat. Radio Republik Indonesia. http://rri.co.id/manado/post/berita/593054/sulut_update/mengakhiri_tahun_2 018_di_sulut_perkara_cerai_meningkat.html

Edwards III, G. C. (1984). Public Policy Implementing. Jai Press Inc.

Hakim, M. L. (2016). Kursus Pra-Nikah: Konsep dan Implementasinya (Studi Komparatif Antara BP4 KUA Kecamatan Pontianak Timur dengan GKKB Jemaat Pontianak). Al-'Adalah, 13(2), 141-154.

Hamalik, O. (2007). Dasar-dasar Pengembangan Kurikulum. PT. Remaja Rosdakarya.

Hogg, M. A., \& Abrams, D. (1988). Social Identifications: A Social Psychology of Intergroup Relations and Group Processes. Routledge.

Jefry. (2018). Kemenag Beri Bimbingan Pra Nikah Kepada 25 Pasangan Catin. Lensa Sulut. http://www.lensasulut.com/2018/12/13/kemenag-beribimbingan-pra-nikah-kepada-25-pasangan-catin/

Kemendikbud, K. P. dan K. R. I. (2019). Implementasi. KBBI Kemendikbud. https://kbbi.kemdikbud.go.id/entri/implementasi

Kurniawan, N. H. (2018). Program Bimwin: Belajar Rahasia Nikah, Bukan Belajar Nikah Rahasia. Bimas Islam Direktorat Jenderal Bimbingan Masyarakat Islam. https://bimasislam.kemenag.go.id/post/berita/---program-bimwinbelajar-rahasia-nikah-bukan-belajar-nikah-rahasia

Munawwir, A. W. (1997). Kamus Al-Munawwir. Pustaka Progresif.

Rangkuti, F. (2015). Analisis SWOT Teknik Membedah Kasus Bisnis. PT. Gramedia Pustaka Utama.

Ranti, F. (2019). Kemenag Manado Gelar Bimbingan Masyarakat Islam, Berikut Sejumlah Kegiatannya! Tribun Manado. https://manado.tribunnews.com/2019/04/25/kemenag-manado-gelarbimbingan-masyarakat-islam-berikut-sejumlah-kegiatannya 
RI, K. A. (2016). Modul Bimbingan Perkawinan Untuk Calon Pengantin. Puslitbang Bimas Agama danLayanan Keagamaan Badan Litbang dan Diklat Kementerian Agama.

RI, K. A. (2017). Fondasi Keluarga Sakinah Bacaan Mandiri Calon Pengantin. Direktorat Bina KUA dan Keluarga Sakinah Ditjen Bimas Islam.

Rofiah, N., \& Kustini. (2016). Modul Bimbingan Perkawinan Untuk Calon Pengantin. Direktorat Bina KUA dan Keluarga Sakinah Direktorat Jenderal Bimbingan Masyarakat Islam Kementerian Agama RI bekerjasama dengan Puslitbang Bimas Agama dan Layanan Keagamaan Badan Litbang dan Diklat Kementerian Agama RI.

Sekeon, R. (2019). Perkara Perceraian Jadi Paling Menonjol di Pengadilan Negeri Manado Sepanjang Januari-Agustus 2019. Tribun Manado.

Wahab, Z., Supardin, \& F. (2017). Proses Pelaksanaan Kursus Calon Pengantin di Kantor Urusan Agama Kecamatan Tamalanrea dan Kecamatan Biringkanaya. Jurnal Diskursus Islam, 5(2), 146-160.

Wibawa, S. (1994). Kebijakan Publik. Intermediia. 